\title{
Spinal column shortening versus revision detethering for recurrent adult tethered cord syndrome: a preliminary comparison of perioperative and clinical outcomes
}

\author{
${ }^{*}$ Can Zhang, MD, , Chih-Chang Chang, MD, ,,3,4 Praveen V. Mummaneni, MD, ${ }^{1}$ Chenghua Yuan, MD, ${ }^{2}$ \\ Sanjay Dhall, MD, ${ }^{1}$ Fengzeng Jian, MD, ${ }^{2}$ Nalin Gupta, MD, PhD, ${ }^{1}$ and Dean Chou, MD ${ }^{1}$ \\ 'Department of Neurosurgery, University of California, San Francisco, California; ${ }^{2}$ Department of Neurosurgery, Xuanwu Hospital \\ Capital Medical University, Beijing, China; ${ }^{3}$ Department of Neurosurgery, Taipei Veterans General Hospital, Taipei; and ${ }^{4}$ School of \\ Medicine, National Yang-Ming University, Taipei, Taiwan
}

OBJECTIVE Recurrent tethered cord syndrome (TCS), believed to result from tension on the distal portion of the spinal cord, causes a constellation of neurological symptoms. Detethering surgery has been the traditional treatment for TCS. However, in cases of recurrent TCS, there is a risk of new neurological deficits developing, and subsequent retethering is difficult to prevent. Spinal column shortening has been proposed as an alternative technique to reduce the tension on the spinal cord without incurring the morbidity of revision surgery on the spinal cord. The authors compared the perioperative outcomes and morbidity of patients who were treated with one or the other procedure.

METHODS The medical records of 16 adult patients with recurrent TCS who were treated between 2005 and 2018 were reviewed. Eight patients underwent spinal column shortening, and 8 patients underwent revision detethering surgery. Patient demographics, clinical outcomes, and perioperative factors were analyzed. The authors include a video to illustrate their technique of spinal column shortening.

RESULTS Within the spinal column shortening group, no patients experienced any complications, and all 8 patients either improved or stabilized with regard to lower-extremity and bowel and bladder function. Within the revision detethering group, 2 patients had worsening of lower-extremity strength, 3 patients had worsening of bowel and bladder function, and 1 patient had improvement in bladder function. Also, 3 patients had wound-related complications. The median estimated blood loss was $731 \mathrm{ml}$ in the shortening group and $163 \mathrm{ml}$ in the revision detethering group. The median operative time was 358 minutes in the shortening group and 226 minutes in the revision detethering group.

CONCLUSIONS Clinical outcomes were comparable between the groups, but none of the spinal column shortening patients experienced worsening, whereas 3 of the revision detethering patients did and also had wound-related complications. Although the operative times and blood loss were higher in the spinal column shortening group, this procedure may be an alternative to revision detethering in extremely scarred or complex wound revision cases.

https://thejns.org/doi/abs/10.3171/2019.12.SPINE19659

KEYWORDS spinal column shortening; revision detethering; adult tethered cord syndrome; osteotomy; recurrent tethered cord syndrome; congenital

$\mathrm{T}$ ETHERED cord syndrome (TCS) consists of a constellation of neurological symptoms and signs, including motor and sensory deficits of the lower extremities, pain, bowel and bladder dysfunction, and sexual dysfunction. ${ }^{9,29}$ It is believed to be caused by traction on the distal end of the spinal cord due to pathological changes such as a thickened filum terminale, spinal cord lipoma, lipo- myelomeningocele, and arachnoid adhesions. ${ }^{27,29}$ Although not all patients with radiological evidence of a tethered spinal cord will develop new symptoms, the indications for surgery include new motor deficits, neurogenic pain, and deterioration of urinary function. ${ }^{1,3,22,29}$

Detethering surgery has been a standard procedure for TCS in children and adults. ${ }^{15}$ Although an overall benefit

ABBREVIATIONS EBL = estimated blood loss; PSO = pedicle subtraction osteotomy; TCS = tethered cord syndrome; UCSF = University of California, San Francisco; VAS

= visual analog scale.

SUBMITTED June 3, 2019. ACCEPTED December 2, 2019.

INCLUDE WHEN CITING Published online February 7, 2020; DOI: 10.3171/2019.12.SPINE19659.

${ }^{*}$ C.Z. and C.C.C. contributed equally to this work. 
with untethering procedures has been reported, interpretation of these results is difficult due to the heterogeneity of the patient population and variations in the surgical techniques used. ${ }^{10,15,17,20,24,26}$ In adults, TCS usually occurs in the setting of a previously repaired congenital anomaly with a structurally abnormal spinal cord attached to an overlying soft-tissue scar. Detaching the spinal cord from the soft tissues can often result in new neurological deficits, often the same deficits that are intended to be reversed by the procedure. In addition, the occurrence of spinal cord retethering after the index surgery for detethering has been reported to be up to $50 \%{ }^{9,15,16,20}$ Operative complications such as CSF leakage, new-onset weakness, sensory loss, bladder dysfunction, and wound healing issues are frequently reported. ${ }^{3,9,15,16,24,25}$ In particular, detethering procedures in patients with spinal cord lipomas or dysraphic conditions have poor outcomes after surgery. ${ }^{13}$ Therefore, alternative options should be considered for those patients in whom detethering procedures may result in a higher likelihood of neurological deficits.

Based on a cadaveric study reported by Grande et al., ${ }^{4}$ spinal column shortening has been shown to be an effective method to reduce the tension of the spinal cord and nerve roots. This technique was first used as a treatment for a low-lying conus medullaris by Kokubun et al..$^{14}$ It has been shown that a 15 - to $25-\mathrm{mm}$ thoracolumbar osteotomy can significantly reduce spinal cord tension. ${ }^{4}$ To date, only a few clinical studies have reported the outcomes of spinal column shortening for the treatment of TCS. ${ }^{2,6-8,14,19,23,28} \mathrm{We}$ have used spinal column shortening in adult patients because this group has reached skeletal maturity and future growth is not an issue. The purpose of this study was to compare the outcomes of revision detethering with those of spinal column shortening in adults with recurrent TCS.

\section{Methods \\ Patient Cohort}

A retrospective chart review of adults who were treated from 2005 to 2018 at the University of California, San Francisco (UCSF), with either spinal column shortening or revision detethering for recurrent TCS was performed. This study was approved by the Committee on Human Research. Inclusion criteria were 18 years or older, MR images demonstrating a tethered cord, clinical symptoms related to the tethered cord, and a surgical procedure to treat the TCS. Patients were excluded if they were younger than 18 years, had active malignancy or infection, or had a traumatic cause of their symptoms. Records were reviewed for preoperative symptoms, postoperative neurological function, bowel and bladder function before and after surgery, operative times, estimated blood loss (EBL), and type of surgeries.

\section{Surgical Procedure}

\section{Revision Detethering}

For the revision detethering cases, the patients were placed prone, and revision laminectomies were performed. With the aid of the operating microscope, the dura was reopened, and the spinal cord was identified. The spinal cord was gently dissected and freed off the dura using mi- croinstruments. Because of the overlap between pediatric and adult neurosurgery, these cases were performed jointly by a pediatric neurosurgeon and an adult spinal neurosurgeon. Neuromonitoring was always used, and, after adequate detethering was performed, the dura was closed. An expansion duraplasty was performed only if it was felt intraoperatively that there was not enough room for the spinal cord and nerve roots with direct primary closure. If primary closure would not compress the neural elements, then a primary closure was performed. However, if the primary closure would result in constriction of the neural elements, then a duraplasty was also performed. Thus, each case was addressed individually based on intraoperative findings. In complex wound revision cases, the plastic surgery team was also involved to close the wound. These patients were kept flat in bed for approximately $2-3$ days, depending on the quality of the dura and the quality of the closure.

\section{Spinal Column Shortening}

The procedure has been described in detail elsewhere, ${ }^{6,7}$ but we will briefly mention our technique here. The level of the osteotomy chosen was usually at the thoracolumbar junction. This level was chosen so that the surgery was away from the previous surgery, yet close enough to the tether that it could be effective. In addition, L1 or L2 was usually chosen as the distal level of fusion in order to try to avoid accelerating degeneration of the lumbar spine. In most cases, instrumentation at 2 levels above and below was performed. Laminectomies at the osteotomy site and above and below were performed. The pedicles were removed, and the lateral walls were dissected. A temporary rod was placed. The vertebral body was decancellated, and the lateral walls and posterior cortex were removed. The anterior wall was shaved paper thin using a high-speed burr, but not penetrated with the burr, which was confirmed with fluoroscopy. After the anterior cortex was thinned, the entire spinal column was shortened by closure of the osteotomy with gentle compression on the screws. Neuromonitoring was used, and, if there were any changes, the compression was released. The other rod was placed, the screws were tightened, and arthrodesis was performed with local osteotomy and laminectomy bone (Fig. 1 and Video 1).

VIDEO 1. Surgical video demonstrating the technique of spinal column shortening. Copyright Dean Chou. Published with permission. Click here to view.

No lumbar bracing or casting was used in any of the spinal shortening cases.

\section{Results}

Sixteen patients met the inclusion criteria; 8 patients underwent spinal column shortening, and 8 patients underwent revision spinal cord detethering. The median ages were 47.5 and 48 years, respectively. The mean follow-up was 2.1 years (range 0.6-3.6 years) in the spinal column shortening group and 3.2 years (range $0.4-13$ years) in the revision detethering group. Of the patients in the spinal column shortening cohort, the median operative time was 358 minutes, and the median EBL was $731 \mathrm{ml}$. Within 

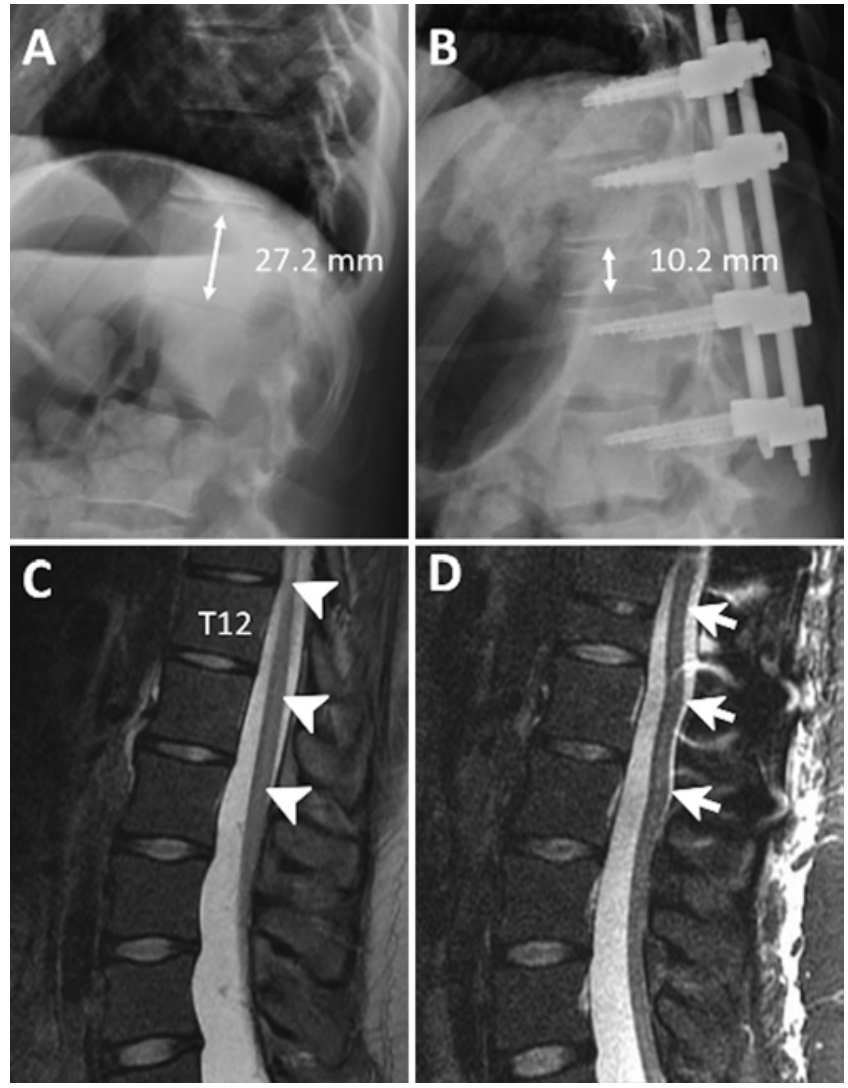

FIG. 1. Preoperative (A) and postoperative (B) lateral radiographs obtained in a patient with a tethered cord who underwent T12 spinal column shortening. The spinal column was shortened from 27.2 to 10.2 $\mathrm{mm}$. Preoperative (C) and postoperative (D) sagittal T2-weighted MR images demonstrating release of the spinal cord tension (arrowheads) after spinal column shortening (arrows). the revision detethering cohort, the median operative time was 226 minutes, and the median EBL was $163 \mathrm{ml}$. Two patients in the revision detethering cohort had duraplasty. Within the revision detethering group, 2 patients had worsening of lower-extremity strength, 3 patients had worsening of bowel and bladder function, and 1 patient had improvement of bladder function. The detethering cohort had 3 wound-related complications, with 2 CSF leaks and 1 wound infection (Table 1). In the spinal column shortening group, 6 of 8 patients had improvement in their preoperative pain, and 4 of 8 patients had improvement in their urinary function. In the detethering cohort, the mean visual analog scale (VAS) score for back pain decreased from 5.8 to 2.3 , and that for leg pain decreased from 4.5 to 2 . In the spinal column shortening group, the mean VAS score for back pain decreased from 8.4 to 4.3 , and that for leg pain decreased from 6 to 2.2. The numbers in each group were insufficiently powered to calculate a statistical difference. None of the spinal column shortening patients had worsening of neurological or bowel and bladder function, and none had perioperative complications (Tables 2 and 3).

\section{Discussion}

In children, symptoms caused by TCS are attributed to growth and lengthening of the spinal column and spinal cord. In adults, although growth is complete, symptoms are believed to arise from daily motion and activity in the setting of chronic tension on the distal spinal cord. Such activity can lead to neurogenic pain, motor and sensory neurological deficits, and worsening bowel and bladder function. In cases without prior surgery or spina bifida, a primary filum terminale release can be performed in a straightforward manner with minimal sequelae. However, in cases of recurrent tethering, previous surgery, abnormal soft-tissue coverage of the posterior lumbar spine, dural ectasia, and congenital malformations can increase the

TABLE 1. Demographic summary of revision detethering patients

\begin{tabular}{|c|c|c|c|c|c|c|}
\hline $\begin{array}{l}\text { Age (yrs), } \\
\text { Sex }\end{array}$ & Previous Op & Preop Presentation & $\begin{array}{l}\text { Postop Neurological } \\
\text { Change }\end{array}$ & $\begin{array}{l}\text { Postop Bowel/ } \\
\text { Bladder Change }\end{array}$ & FU (yrs) & Complication \\
\hline $50, \mathrm{M}$ & Detethering $\times 2$ & $\begin{array}{l}\text { Progressive rt leg weakness \& drop } \\
\text { foot }\end{array}$ & $\begin{array}{l}\text { Worsening rt leg weak- } \\
\text { ness, It leg weakness }\end{array}$ & $\begin{array}{l}\text { Urinary reten- } \\
\text { tion }\end{array}$ & 3.8 & Pseudomeningocele \\
\hline $55, M$ & $\begin{array}{l}\text { Detethering in child- } \\
\text { hood }\end{array}$ & $\begin{array}{l}\text { Abnormal sensation of leg, urinary } \\
\text { incontinence since childhood }\end{array}$ & No change & No change & 1.1 & Wound infection \\
\hline $43, \mathrm{~F}$ & $\begin{array}{l}\text { Detethering at age } \\
5 \mathrm{yrs}\end{array}$ & $\begin{array}{l}\text { Back pain, urinary incontinence for } \\
2 \text { yrs }\end{array}$ & Pain improved & No change & 0.5 & None \\
\hline $37, \mathrm{M}$ & $\begin{array}{l}\text { Detethering at age } \\
6 \text { mos }\end{array}$ & $\begin{array}{l}\text { Severe leg pain, sexual dysfunction, } \\
\text { progressive urinary retention }\end{array}$ & Pain improved & Improved & 0.4 & None \\
\hline $55, \mathrm{~F}$ & $\begin{array}{l}\text { Detethering surgery } \\
\text { in adulthood }\end{array}$ & Back \& leg pain & Persisting pain & No change & 1.3 & None \\
\hline $50, F$ & $\begin{array}{l}\text { Detethering in } \\
\text { adulthood }\end{array}$ & Lt calf atrophy, urinary retention & No change & No change & 1 & None \\
\hline $46, F$ & Detethering $\times 3$ & Neurogenic bladder & Leg weakness by 1 grade & Worsening & 13 & CSF leak \\
\hline $35, M$ & $\begin{array}{l}\text { Detethering \& } \\
\quad \text { lipoma excision }\end{array}$ & $\begin{array}{l}\text { Bilat leg weakness, bowel/bladder } \\
\text { dysfunction }\end{array}$ & $\begin{array}{l}\text { Decreased sensation } \\
\text { of leg }\end{array}$ & No change & 4.5 & $\begin{array}{l}\text { IONM signal change, } \\
\text { surgery stopped }\end{array}$ \\
\hline
\end{tabular}

$\mathrm{FU}=$ follow-up; IONM = intraoperative neuromonitoring. 
TABLE 2. Demographic summary of spinal column shortening patients

\begin{tabular}{|c|c|c|c|c|c|c|c|c|c|c|}
\hline $\begin{array}{l}\text { Case } \\
\text { No. }\end{array}$ & $\begin{array}{l}\text { Age } \\
\text { (yrs), } \\
\text { Sex }\end{array}$ & Prior Op & $\begin{array}{c}\text { Preop } \\
\text { Presentation }\end{array}$ & $\begin{array}{l}\text { Postop } \\
\text { Neurological } \\
\text { Change }\end{array}$ & $\begin{array}{l}\text { Postop Bowel/ } \\
\text { Bladder Change }\end{array}$ & $\begin{array}{l}\text { Osteotomy } \\
\text { Level }\end{array}$ & $\begin{array}{l}\text { No. of } \\
\text { Fusion } \\
\text { Levels }\end{array}$ & $\begin{array}{l}\text { Levels } \\
\text { Fused }\end{array}$ & $\begin{array}{l}\text { FU } \\
\text { (yrs) }\end{array}$ & Complication \\
\hline 1 & $28, M$ & $\begin{array}{l}\text { Detethering } \\
\text { in child- } \\
\text { hood }\end{array}$ & $\begin{array}{l}\text { Back pain, rt lower- } \\
\text { extremity weakness, } \\
\text { urinary frequency \& } \\
\text { incontinence }\end{array}$ & $\begin{array}{c}\text { Abnormal sensa- } \\
\text { tion improved, } \\
\text { persisting pain }\end{array}$ & Improved & $\mathrm{T} 12$ & 5 & T10-L2 & 3.5 & None \\
\hline 2 & $32, \mathrm{M}$ & $\begin{array}{l}\text { Detethering } \\
\text { in child- } \\
\text { hood }\end{array}$ & $\begin{array}{l}\text { Back pain, neurogenic } \\
\text { bladder }\end{array}$ & Pain improved & Improved & $\mathrm{T} 12$ & 5 & T10-L2 & 3.6 & None \\
\hline 3 & $54, \mathrm{M}$ & $\begin{array}{l}\text { Detethering } \\
\text { in adult- } \\
\text { hood }\end{array}$ & Back \& leg pain & Partially improved & No change & T11 & 5 & T9-L1 & 2.7 & None \\
\hline 4 & $59, F$ & $\begin{array}{l}\text { Thoracic } \\
\text { tumor } \\
\text { removal }\end{array}$ & $\begin{array}{l}\text { Leg weakness, urinary } \\
\text { incontinence, buttocks } \\
\text { burning pain, radiation } \\
\text { pain }\end{array}$ & $\begin{array}{l}\text { Abnormal sensa- } \\
\text { tion improved, } \\
\text { pain improved }\end{array}$ & Improved & T10 & 5 & T8-12 & 2.7 & None \\
\hline 5 & $44, F$ & $\begin{array}{l}\text { Detethering } \\
\text { \& tumor } \\
\text { biopsy }\end{array}$ & $\begin{array}{l}\text { Bowel/bladder inconti- } \\
\text { nence, back \& leg pain }\end{array}$ & Leg pain improved & Improved & $\mathrm{T} 11$ & 5 & T9-L1 & 0.6 & None \\
\hline 6 & $52, F$ & $\begin{array}{l}\text { Detethering } \\
\text { in child- } \\
\text { hood }\end{array}$ & Burning sensation in feet & Pain improved & No change & T11 & 5 & T9-L1 & 0.8 & None \\
\hline 7 & $18, F$ & $\begin{array}{l}\text { Detethering } \\
\times 3\end{array}$ & Back pain, leg weakness & Pain improved & No change & $\mathrm{T} 12$ & 4 & T10-L1 & 1.9 & None \\
\hline 8 & $51, \mathrm{M}$ & $\begin{array}{l}\text { Detethering } \\
\text { in adult- } \\
\text { hood }\end{array}$ & $\begin{array}{l}\text { Urinary incontinence, leg } \\
\text { weakness }\end{array}$ & No change & No change & T10 & 5 & T8-12 & 0.9 & None \\
\hline
\end{tabular}

complexity and length of the procedure. Direct manipulation of the spinal cord is believed to cause new neurological deficits. Poor wound healing of the posterior lumbar spine with wound breakdown, infection, and CSF leak are common complications. Spinal column shortening avoids some of these complications but has its own specific complications.

Lee et al. reported their experience with 60 patients undergoing revision spinal detethering and noted a woundrelated complication rate of $22 \%$ (CSF leak, infection, meningitis); 2 patients worsened neurologically. ${ }^{15}$ However, they reported that up to $90 \%$ of patients had overall improvement. Selcuki et al. reported up to $95 \%$ improvement with spinal cord detethering in adults; however, it is unknown how many of these patients were undergoing revision detethering. ${ }^{24}$ Klekamp reported that in primary detethering procedures, there was an $89 \%$ improvement rate. ${ }^{13}$ However, when performing revision detethering surgery in patients with either dysraphic cysts (dermoid, epidermoid, or neurenteric cyst) or lipomas, clinical deterioration occurred in all patients within 10 years. He also commented that the "benefit of secondary operations... was limited," and "revision surgery in patients with complex dysraphic lesions should be performed in exceptional cases only." Sofuoglu et al. reported 23 cases of adult spinal cord detethering, with a $26 \%$ complication rate related to the surgical wound (CSF leak and infections). ${ }^{26}$ They concluded that spinal cord detethering in adults is a "complex procedure and has serious complications." Thus, based on previous publications, it appears that either primary detethering procedures or detetherings without dysraphic features or lipoma probably have good outcomes, but complex revision cases with dysraphic cysts or lipoma may carry increased morbidity with revision detethering.

Spinal column shortening performed via a vertebral osteotomy as an alternative to revision detethering has been described by several authors as case reports with successful initial outcomes. ${ }^{6,11,12,18}$ There are very few reports of comparison studies, however. In 2010, Hsieh et al. noted that there were only 18 reported cases of spinal column shortening to date in the literature. ${ }^{7}$ Nakashima et al. reported 3 cases of spinal column shortening and compared them with 11 cases of detethering for a total of 14 cases. ${ }^{19}$ They concluded that spinal column shortening had results comparable to those of detethering, and they also stated that spinal column shortening resulted in "better clinical improvement than untethering surgery." Hou et al. reported 15 cases of spinal column shortening with no complications and good outcomes. ${ }^{5}$ Kokubun et al. reported 8 cases of spinal column shortening in patients with lipomyelomeningocele; they reported that 6 patients reported initial improvement, but 4 of those 6 patients subsequently worsened. ${ }^{14}$ Aldave et al. reported on 7 patients, both adults and children, who underwent spinal column shortening, 
TABLE 3. Preoperative and postoperative mean VAS scores

\begin{tabular}{lcccccccc}
\hline \multirow{2}{*}{ Cohort } & \multicolumn{4}{c}{ VAS Back } & & \multicolumn{3}{c}{ VAS Leg } \\
\cline { 2 - 4 } \cline { 7 - 8 } & Preop & Postop & Improvement & & Preop & Postop & Improvement \\
\hline Revision detethering $(n=6)$ & 5.8 & 2.3 & 3.5 & & 4.5 & 2 & 2.5 \\
\hline Spinal shortening $(n=8)$ & 8.4 & 4.3 & 4.1 & & 6 & 2.2 & 3.8 \\
\hline
\end{tabular}

and they concluded that spinal column shortening was a "safe and efficacious alternative to traditional untethering."' Thus, most reports have shown that spinal column shortening has been beneficial, and the complication rate is acceptably low, especially when compared with revision detethering.

There are possibly 4 main reasons why less blood loss is observed with spinal column shortening than with traditional 3-column osteotomies (e.g., lumbar pedicle subtraction osteotomy [PSO]). First, the lower thoracic vertebrae are much smaller than lumbar vertebrae. A small vertebra makes dissection, osteotomy, and hemostasis less onerous than a larger lumbar vertebra, resulting in decreased blood loss. Second, before performing the osteotomy, we first perform bipolar cauterization of the epidural venous plexus because, once the osteotomy is performed through the venous plexus, significant bleeding ensues that cannot be tamponaded or coagulated. Also, during lateral vertebral wall dissection, the segmental vessels are coagulated if they are bleeding and not simply tamponaded. Third, 2 of the cases were performed in a mini-open fashion. This means that the pedicle screws were placed in a percutaneous manner, and only the area over the osteotomy was opened in the traditional manner. This mini-open approach may have also accounted for the decrease in blood loss because of the smaller surgical opening. Finally, the fusion levels were mainly in the thoracic spine and upper lumbar spine. These levels generally have less tissue to dissect through and are closer to the skin than are levels of the deep lumbar spine, which subsequently results in less muscular dissection and exposure of bleeding soft tissue.

As summarized earlier, revision detethering entails surgery that is much more challenging than initial detethering and is associated with a higher complication rate. ${ }^{13}$ To our knowledge, this paper provides the first comparison of revision detethering versus spinal column shortening exclusively in adult patients with recurrent tethering. Our results are comparable to those of previous studies, but we also found increased morbidity and complications in the detethering group, most likely because other studies combined initial procedures and revision procedures, whereas our series included only patients with recurrent TCS. We did find that operative times were longer and EBL was greater in patients who underwent spinal column shortening, which is not unexpected given that these cases were essentially 3-column osteotomies (albeit on a smaller scale than a lumbar osteotomy performed for deformity) and multilevel instrumented fusions. Although there have been attempts to decrease morbidity associated with this procedure with less invasive techniques, ${ }^{21}$ this procedure has not yet been widely adopted, and open, traditional surgery remains the mainstay of spinal column shortening.
Despite the added morbidity of spinal column shortening, outcomes nonetheless remain promising compared with revision detethering.

Despite the fact that 3-column osteotomies were performed in the spinal shortening group, there were no complications. There are potentially several reasons for this low rate of complications. The area of surgery is intentionally chosen to be far away from the previous surgery, and thus, the region of surgery did not have scar tissue over the dura, decreasing the complication rate with regard to CSF leak. Another reason is that the nerve roots in the lower thoracic spine can be sacrificed or damaged during surgery without resulting in a neurological deficit. The third reason for the low complication rate is that there is no angular correction of the spine, unlike with traditional PSO, only a shortening, thus decreasing the tension on the spinal cord without adding new angular stress. Another reason is that with lumbar PSO, there is psoas muscle dissection (and concomitant lumbar plexus manipulation) that can result in postoperative weakness unrelated to spinal cord or intraspinal nerve manipulation. Since the shortening osteotomy is performed in the lower thoracic spine, the psoas muscle and the plexus cannot be damaged or irritated from the lateral wall dissection. In addition, these shortening procedures are essentially performed in virgin areas of the spine, far away from poorly healed previous incisions and scar tissue. However, because of the short follow-up, long-term complications (pseudarthrosis, implant failure, junctional problems) may not be recorded in this preliminary series.

There are several limitations of this study. First, the cohort was small with only 16 patients in total -8 patients in the spinal column shortening group and 8 in the revision detethering group-which limits the statistical power that could be achieved. However, the condition is not that common. Moreover, almost all previously published studies have fewer than 20 patients, with most studies reporting single-digit numbers. Also, the uniqueness of this study is that it represents recurrent tethering in adults; thus, all 16 patients had previously undergone detethering, making these 2 cohorts more homogeneous than those in many other reports, which may have included a compendium of tethered fila, lipomyelomeningoceles, recurrent tethers, and virgin cases. Another limitation of this study is the lack of routine postoperative urodynamic measurements. Although many of the patients underwent preoperative urodynamic studies, formal postoperative urodynamic studies were not performed because of 1) the invasiveness of the test, 2) the cost, and 3) the response from the patient in terms of subjective urinary function. Thus, quantitative urodynamics would have been ordered only for worsening urological function, and none of the spinal column 
shortening patients had worsening urological function. An additional potential limitation is inclusion of any postoperative tumor patients, obfuscating the diagnosis of spinal cord tethering. However, we would propose that in such cases, the actual tethering is not due to the tumor but rather due to scar tissue and arachnoid adhesions arising as a result of previous resection. Moreover, the postoperative MR images showed no evidence of enhancement, suggesting that it was unlikely that a recurrent tumor was causing spinal cord tethering. Another limitation of this study is whether the potential differences observed were related to the surgical technique performed in the revision detethering cohort and in the spinal shortening cohort. However, the surgical cases were contributed equally by 4 senior staff surgeons from UCSF, and all cases were discussed at a group spine conference; therefore, the differences in skill set and technical abilities may not have been as much of a factor because all surgeries were performed by the same 4 senior staff surgeons from UCSF. Although the perioperative morbidity of spinal column shortening appears acceptable, long-term outcomes will need to be assessed to evaluate the durability of spinal column shortening.

\section{Conclusions}

In the comparison of spinal column shortening with revision detethering in adult recurrent TCS, we found that there were more complications with revision detethering and that neurological outcomes were acceptable in spinal column shortening patients. Although there was increased blood loss and operative time in the spinal column shortening cohort, shortening may represent an alternative in patients who have lipomyelomeningoceles, dysraphic cysts, or complex wound issues.

\section{References}

1. Agarwalla PK, Dunn IF, Scott RM, Smith ER: Tethered cord syndrome. Neurosurg Clin N Am 18:531-547, 2007

2. Aldave G, Hansen D, Hwang SW, Moreno A, Briceño V, Jea A: Spinal column shortening for tethered cord syndrome associated with myelomeningocele, lumbosacral lipoma, and lipomyelomeningocele in children and young adults. J Neurosurg Pediatr 19:703-710, 2017

3. Bui CJ, Tubbs RS, Oakes WJ: Tethered cord syndrome in children: a review. Neurosurg Focus 23(2):E2, 2007

4. Grande AW, Maher PC, Morgan CJ, Choutka O, Ling BC, Raderstorf TC, et al: Vertebral column subtraction osteotomy for recurrent tethered cord syndrome in adults: a cadaveric study. J Neurosurg Spine 4:478-484, 2006

5. Hou Y, Sun J, Shi J, Guo Y, Wang Y, Shi G, et al: Clinical evaluation of an innovative operative procedure in the treatment of the tethered cord syndrome. Spine J 18:998-1004, 2018

6. Hsieh PC, Ondra SL, Grande AW, O'Shaughnessy BA, Bierbrauer K, Crone KR, et al: Posterior vertebral column subtraction osteotomy: a novel surgical approach for the treatment of multiple recurrences of tethered cord syndrome. J Neurosurg Spine 10:278-286, 2009

7. Hsieh PC, Stapleton CJ, Moldavskiy P, Koski TR, Ondra SL, Gokaslan ZL, et al: Posterior vertebral column subtraction osteotomy for the treatment of tethered cord syndrome: review of the literature and clinical outcomes of all cases reported to date. Neurosurg Focus 29(1):E6, 2010

8. Huang SL, Peng J, Yuan GL, Ding XY, He XJ, Lan BS: A new model of tethered cord syndrome produced by slow traction. Sci Rep 5:9116, 2015

9. Iskandar BJ, Fulmer BB, Hadley MN, Oakes WJ: Congenital tethered spinal cord syndrome in adults. Neurosurg Focus 10(1):e7, 2001

10. Kang JK, Yoon KJ, Ha SS, Lee IW, Jeun SS, Kang SG: Surgical management and outcome of tethered cord syndrome in school-aged children, adolescents, and young adults. J Korean Neurosurg Soc 46:468-471, 2009

11. Kanno H, Aizawa T, Ozawa H, Hoshikawa T, Itoi E, Kokubun S: Spine-shortening vertebral osteotomy in a patient with tethered cord syndrome and a vertebral fracture. Case report. J Neurosurg Spine 9:62-66, 2008

12. Kawamura I, Ishido Y, Zenmyo M, Yamamoto T, Kagawa Y, Komiya S, et al: Pedicle subtraction osteotomy for adult tethered cord syndrome with lumbar canal stenosis: report of two cases. Int J Neurosci 120:735-737, 2010

13. Klekamp J: Tethered cord syndrome in adults. J Neurosurg Spine 15:258-270, 2011

14. Kokubun S, Ozawa H, Aizawa T, Ly NM, Tanaka Y: Spineshortening osteotomy for patients with tethered cord syndrome caused by lipomyelomeningocele. J Neurosurg Spine 15:21-27, 2011

15. Lee GY, Paradiso G, Tator CH, Gentili F, Massicotte EM, Fehlings MG: Surgical management of tethered cord syndrome in adults: indications, techniques, and long-term outcomes in 60 patients. J Neurosurg Spine 4:123-131, 2006

16. Lew SM, Kothbauer KF: Tethered cord syndrome: an updated review. Pediatr Neurosurg 43:236-248, 2007

17. Maroun FB, Jacob JC, Murray GP: Tethered cord syndrome in adults. Surg Neurol 54:403, 2000

18. Miyakoshi N, Abe E, Suzuki T, Kido T, Chiba M, Shimada Y: Spine-shortening vertebral osteotomy for tethered cord syndrome: report of three cases. Spine (Phila Pa 1976) 34:E823-E825, 2009

19. Nakashima H, Imagama S, Matsui H, Yukawa Y, Sato K, Kanemura T, et al: Comparative study of untethering and spine-shortening surgery for tethered cord syndrome in adults. Global Spine J 6:535-541, 2016

20. Romagna A, Suchorska B, Schwartz C, Tonn JC, Zausinger $\mathrm{S}$ : Detethering of a congenital tethered cord in adult patients: an outcome analysis. Acta Neurochir (Wien) 155:793-800, 2013

21. Safaee MM, Winkler EA, Chou D: Mini-open spinal column shortening for the treatment of adult tethered cord syndrome. J Clin Neurosci 44:315-319, 2017

22. Schneider SJ, Rosenthal AD, Greenberg BM, Danto J: A preliminary report on the use of laser-Doppler flowmetry during tethered spinal cord release. Neurosurgery 32:214-218, 1993

23. Seki T, Hida K, Yano S, Houkin K: Surgical outcomes of pediatric patients with asymptomatic tethered cord syndrome. Asian Spine J 12:551-555, 2018

24. Selcuki M, Mete M, Barutcuoglu M, Duransoy YK, Umur AS, Selcuki D: Tethered cord syndrome in adults: experience of 56 patients. Turk Neurosurg 25:922-929, 2015

25. Shih P, Halpin RJ, Ganju A, Liu JC, Koski TR: Management of recurrent adult tethered cord syndrome. Neurosurg Focus 29(1):E5, 2010

26. Sofuoglu OE, Abdallah A, Emel E, Ofluoglu AE, Gunes M, Guler B: Management of tethered cord syndrome in adults: experience of 23 cases. Turk Neurosurg 27:226-236, 2017

27. Steinbok P, MacNeily AE: Section of the terminal filum for occult tethered cord syndrome: toward a scientific answer. Neurosurg Focus 23(2):E5, 2007

28. Wang H, Sun J, Wang Y, Wu Z, Xu T, Chen K, et al: [Homogeneous spinal-shortening axial decompression procedure for tethered cord syndrome.] Zhonghua Yi Xue Za Zhi 95:1801-1806, 2015 (Chinese)

29. Yamada S: Tethered cord syndrome in adults and children. Neurol Res 26:717-718, 2004 


\section{Disclosures}

Dr. Mummaneni: consultant for DePuy Synthes, Globus, and Stryker; direct stock ownership in Spinicity/ISD; support of nonstudy-related clinical or research effort from NREF, AOSpine, and ISSG; royalties from DePuy Synthes, Thieme Publishers, and Springer Publishers; and honoraria from Spineart. Dr. Dhall: consultant for DePuy Synthes and Globus Medical. Dr. Chou: consultant for Medtronic and Globus and royalties from Globus.

\section{Author Contributions}

Conception and design: Chou, Mummaneni. Acquisition of data: all authors. Analysis and interpretation of data: Chou, Zhang,

Chang, Yuan, Jian, Gupta. Drafting the article: Chou, Zhang. Crit- ically revising the article: Chou, Mummaneni, Gupta. Reviewed submitted version of manuscript: Chou. Approved the final version of the manuscript on behalf of all authors: Chou.

\section{Supplemental Information}

Videos

Video 1. https://vimeo.com/379013337.

\section{Correspondence}

Dean Chou: University of California, San Francisco, CA. dean. chou@ucsf.edu. 